\title{
Digital services in Poland and the Far East - comparative analysis
}

\section{Analiza porównawcza usług cyfrowych między Polską, a Dalekim Wschodem}

\author{
Dominik Klej* \\ Department of Computer Science, Lublin University of Technology, Nadbystrzycka 36B, 20-618 Lublin, Poland
}

\begin{abstract}
The following article focuses on ilustrating the content of the master thesis with the same title. The methodology of developed by author digital indicator will be presented, as well as the results and conclusions based on the comparative analysis. The research concerns the comparative analysis between digital services in Poland, Japan and China, based on the IDI, WDC and ITC digital indicators. The analysis is based on publicly available data of digitization.
\end{abstract}

Keywords: digital services; DAI; Poland; Japan

\section{Streszczenie}

Artykuł skupia się na zobrazowaniu treści pracy magisterskiej o tym samym tytule. Przedstawiona w nim zostanie metodologia opracowanego, autorskiego wskaźnika cyfryzacji, a także jego wyniki i wnioski na podstawie przeprowadzonych badań porównawczych. Badania dotyczą analizy porównawczej pomiędzy usługami cyfrowymi w Polsce, Japonii oraz Chinach, na podstawie wskaźników cyfryzacji IDI, WDC oraz ITC. Analiza odbywa się na podstawie publicznie dostępnych danych na temat cyfryzacji.

Stowa kluczowe: usługi cyfrowe; DAI; Polska; Japonia

${ }^{*}$ Corresponding author

Email address: dominik.klej@gmail.com (D. Klej)

CPublished under Creative Common License (CC BY-SA v4.0)

\section{Wstęp}

Niniejszy artykuł przedstawia zestawienie wskaźnika cyfryzacji DAI (Digital Adoption Index), opracowanego przez Bank Światowy ze wskaźnikiem DDI (Digital Development Index) opracowanym przez autora artykułu. Celem artykułu jest dostarczenie rzetelnie opracowanych informacji statystycznych oraz wniosków wysnutych na podstawie ich analizy, w sposób transparentny, aby czytelnik mógł się zapoznać $\mathrm{z}$ przebiegiem prowadzonych $\mathrm{w}$ pracy magisterskiej działań, na każdym kroku postępowania pracy. Tak opracowane dane będą mogły w obrazowy sposób zaprezentować różnice pomiędzy wymienionymi krajami, na które osoby zainteresowane niniejszą tematyką, będą mogły się powołać $\mathrm{w}$ dowolnie zdefiniowanym przez siebie celu.

Powodem napisania artykułu jest niewielka ilość aktualnych źródeł informacji i opracowań nawiązujących do przedstawionej w tytule pracy tematyki.

\section{Metodologia i pojęcia}

\subsection{Metodologia}

Do przeprowadzenia analizy porównawczej zostały wykorzystane oficjalne, publicznie dostępne dane (w głównej mierze ze strony Banku Światowego). Zebrane dane poddane zostały obróbce statystycznej oraz interpretacji uzyskanych wyników, na skutek czego zostały opracowane wnioski dotyczące poziomu stopnia cyfryzacji wybranych krajów.

Uzyskane na skutek wyszukiwania dane, zostały odpowiednio podzielone i zgrupowane tematycznie. Na- stępnie z poszczególnych klastrów tematycznych zostały wyliczone średnie ważone.

Wyniki uzyskane na skutek całego opisanego procesu, zostały zestawione i porównane $\mathrm{z}$ wynikami wskaźnika cyfryzacji DAI (Digital Adoption Index), opracowanego przez Bank Światowy.

\subsection{Pojęcia}

W niniejszym podrozdziale zostały przedstawione niezbędne informacje do zrozumienia zagadnień i metodologii działania podczas wykonywanych działań statystycznych $\mathrm{i}$ analiz.

Cyfryzacja - to pojęcie wyrażające rozpowszechnienie oraz skale wpływu technologii informatycznych i techniki cyfrowej na życie codzienne i gospodarkę danego kraju. Cyfryzacja często nazywana jest również „dygitalizacją” lub „digitalizacją”, czyli spolszczoną wersją wyrazu „digitalization”. Jednakże nie można utożsamiać ze sobą tych dwóch pojęć jako, że dygitalizacja oznacza ,nadawanie postaci cyfrowej danym pisanym i drukowanym" [1].

Treści cyfrowe - „to wszelkie informacje, do których użtkownik końcowy posiada dostęp za pośrednictwem sieci, lub innych kanatów pośredniczacych (jak CD lub DVD)." [2]

\subsection{Wykorzystywane dzialania statystyczne}

Jako, że niniejsza praca naukowa opiera się na działaniach porównawczych wykorzystując działania statystyczne, należy wymienić i opisać wszelkie pojęcia wykorzystane i związane z niniejszą pracą magisterską. 
Średnia arytmetyczna ważona - Jest to średnia arytmetyczna elementów, którym przypisywane są różne wagi. Waga poszczególnych elementów średniej służy temu, aby przypisać większe bądź mniejsze znaczenie wybranej wartości, w skali całej obliczanej średniej. Wówczas elementy wchodzące w skład średniej, o większej wadze, będa miały większy wpływ na wartość średniej od elementów posiadających mniejszą wagę. We wzorze 2.1. zmienna $w$ oznacza wagę danej zmiennej wchodzącej w skład średniej.

$$
\bar{x}=\frac{w_{1} x_{1}+w_{2} x_{2}+\cdots+w_{n} x_{n}}{w_{1}+w_{2}+\cdots+w_{n}}
$$

Unitaryzacja - Unitaryzacja zmiennych, jest to działanie polegające na ujednoliceniu zakresu pozyskanych wartości statystycznych. Celem tego zabiegu jest uzyskanie zmiennych o ujednoliconym zakresie zmienności, definiowanym przez różnicę pomiędzy ich wartościami maksymalnymi i minimalnymi w ujęciu klasycznym lub maksimum $\mathrm{z}$ medianowych odchyleń bezwzględnych w ujęciu pozycyjnym, równym stale 1. [3]

Unitaryzacja klasyczna - W unitaryzacji klasycznej parametry normalizacyjne przyjmują wartości z przedziału $[0 ; 1]$. Wartości te można pozyskać za pomocą wzoru 2.2. W tym wzorze $R$ jest wartością danego parametru wchodzącego w skład zakresu liczb poddawanych unitaryzacji.

$$
\frac{R_{1}-\min R}{\max R-\min R}
$$

Normalizacja - „Jest to działalność zmierzająca do uzyskania optymalnego, w danych okolicznościach, stopnia uporządkowania $w$ określonym zakresie, poprzez ustalenie postanowień przeznaczonych do powszechnego i wielokrotnego stosowania, dotyczacych istniejacych lub mogacych wystapić problemów” [3]

\section{Wskaźnik DAI - opis i metodologia}

\subsection{Opis}

Indeks adopcji cyfrowej, jest to złożony, ogólnoświatowy wskaźnik autorstwa Banku Światowego przy współpracy z firmą Microsoft. Wskaźnik ten mierzy poziom adopcji i rozprzestrzeniania się technologii cyfrowych na terenie poszczególnych krajów z całego świata. Miara tego wskaźnika wyznaczana jest $\mathrm{z}$ perspektywy trzech wymiarów ekonomicznych: ludzi, rządu oraz przedsiębiorstw. Index ten opisuje 171 krajów w skali od 0 do 1. Ostateczna miara jest wynikiem obliczenia średniej arytmetycznej z subindeksów. Każdy subindeks obejmuje technologie niezbędne do opisania rozwoju cyfryzacji, takie jak: zwiększenie produktywności i przyspieszenie szeroko zakrojonego rozwoju dla biznesu, poszerzenie możliwości i poprawa dobrobytu dla ludzi oraz zwiększenie wydajności i odpowiedzialności za świadczenie usług dla rządu. Pierwotnie, indeks adopcji cyfrowej został skonstruowany jako część raportu „World Development Report 2016: Digital Divi- dends" [4], a później został zaktualizowany w celu odzwierciedlenia nowych źródeł danych i ulepszonej metodologii. Poprzez pomiar względnej adopcji cyfrowej, wskaźnik DAI staje się użyteczny na potrzeby decydentów w kwestii opracowywania strategii cyfrowych z dostosowanymi politykami promującymi adopcję cyfrową w różnych grupach użytkowników.

\subsection{Metodologia DAI}

Metodologię wyznaczania tego wskaźnika stanowi złożony indeks, który mierzy głębokość i szerokość przyjęcia technologii cyfrowych w 171 krajach, obejmujących każdy region i grupę dochodową. Opiera się na trzech subindeksach sektorowych obejmujących przedsiębiorstwa, ludzi i rządy, przy czym każdy indeks posiada jednakową wagę. DAI (Ekonomia) = DAI (Przedsiębiorstwa) + DAI (Ludzie) + DAI (Rządy) DAI (Przedsiębiorstwa). DAI (Przedsiębiorstwa): Klaster Przedsiębiorstwa to prosta średnia $\mathrm{z}$ czterech znormalizowanych wskaźników: procent firm ze stronami internetowymi, liczba bezpiecznych serwerów, prędkość pobierania i zasięg $3 \mathrm{G}$ w kraju. DAI (Ludzie): klaster Ludzie to prosta średnia z dwóch znormalizowanych wskaźników z Gallup World Poll [5]: mobilny dostęp $\mathrm{w}$ domu i dostęp do Internetu $\mathrm{w}$ domu. DAI (Rząd): Klaster rządowy to prosta średnia $\mathrm{z}$ trzech wskaźników częściowych: podstawowych systemów administracyjnych, usług publicznych online i identyfikacji cyfrowej. Dane dotyczące usług publicznych online są dostarczane przez Indeks usług online ONZ. Dane dotyczące podstawowych systemów administracyjnych identyfikacji cyfrowej zostały zebrane przez Bank Światowy. Wskaźniki złożone są znormalizowane w skali od 0 do 1 , aby zapewnić, że mają one równy wpływ na zmienność wskaźnika ogólnego. W tabelach 1, 2 oraz 3 przedstawiono konstrukcje poszczególnych klastrów wchodzących w skład wskaźnika DAI.

Tabela 1: Przedstawienie klastra biznesowego z uwzględnieniem wag oraz źródeł dla poszczególnych komponentów [6]

\begin{tabular}{|l|l|l|}
\hline Komponent & Waga & Źródło \\
\hline Strony firmowe & $1 / 4$ & WBG Enterprise Surveys \\
\hline Bezpieczne serwery & $1 / 4$ & Netcraft \\
\hline Prędkość pobierania & $1 / 4$ & Ookla NetIndex \\
\hline Zasięg 3G & $1 / 4$ & GSMA \\
\hline
\end{tabular}

Tabela 2: Przedstawienie klastra rządowego z uwzględnieniem wag

\begin{tabular}{|c|c|c|c|}
\hline Komponent & Indykator & Waga & Źródło \\
\hline \multirow{4}{*}{$\begin{array}{c}\text { System zarządzania } \\
\text { informacjami } \\
\text { finansowymi }\end{array}$} & $\begin{array}{c}\text { Wykonanie bu- } \\
\text { dżetu }\end{array}$ & $1 / 20$ & \multirow[t]{6}{*}{ WBG } \\
\hline & $\begin{array}{c}\text { Formuowanie } \\
\text { budżetu }\end{array}$ & $1 / 20$ & \\
\hline & $\begin{array}{c}\text { Pojedyncze konto } \\
\text { skarbowe }\end{array}$ & $1 / 20$ & \\
\hline & $\begin{array}{l}\text { Źródło danych } \\
\text { finansowych }\end{array}$ & $1 / 20$ & \\
\hline \multirow{2}{*}{$\begin{array}{c}\text { System informacji } \\
\text { o zasobach ludz- } \\
\text { kich }\end{array}$} & $\begin{array}{c}\text { Funkcjonalność } \\
\text { HRMIS }\end{array}$ & $1 / 10$ & \\
\hline & $\begin{array}{c}\text { Funkcjonalność } \\
\text { e-płatności }\end{array}$ & $1 / 10$ & \\
\hline
\end{tabular}
oraz źródeł dla poszczególnych komponentów [6] 


\begin{tabular}{|c|c|c|}
\hline E-podatki & $\begin{array}{c}\text { Funkcjonalność } \\
\text { zarządzania po- } \\
\text { datkami }\end{array}$ & $1 / 10$ \\
\cline { 2 - 3 } & $\begin{array}{c}\text { Funkcjonalność } \\
\text { e-zgłoszeń }\end{array}$ & $1 / 10$ \\
\hline e-cła & $\begin{array}{c}\text { Funkcjolaność e- } \\
\text { celna }\end{array}$ & $1 / 5$ \\
\hline e-zamówienia & $\begin{array}{c}\text { Funkcjonalność } \\
\text { e-zamówień }\end{array}$ & $1 / 5$ \\
\hline Dostęp do usług & Zakres usług & $1 / 2$ \\
\hline Podpis cyfrowy & $\begin{array}{c}\text { Funkcjonalność } \\
\text { podpisu }\end{array}$ & $1 / 4$ \\
\hline Funkcje karty & Typ karty & $1 / 8$ \\
\hline & $\begin{array}{c}\text { Funkcje biome- } \\
\text { tryczne }\end{array}$ & \\
\hline
\end{tabular}

Tabela 3: Przedstawienie klastra obywateli z uwzględnieniem wag oraz źródeł dla poszczególnych komponentów [6]

\begin{tabular}{|l|l|l|}
\hline Komponent & Waga & Źródło \\
\hline $\begin{array}{l}\text { Dostęp do urządzeń mobilnych } \\
\text { w domach }\end{array}$ & $1 / 3$ & $\begin{array}{l}\text { Gallup World } \\
\text { Poll }\end{array}$ \\
\hline Dostęp do Internetu w domach & $1 / 3$ & $\begin{array}{l}\text { Gallup World } \\
\text { Poll }\end{array}$ \\
\hline Koszt dostępu do Internetu & $1 / 3$ & TBC \\
\hline
\end{tabular}

\subsection{Wyniki i wnioski}

Tabela 4 przedstawia dane $\mathrm{z}$ ubiegłych lat na temat wyliczonych wskaźników DAI oraz ich subwskaźników dla rozpatrywanych w niniejszym artykule krajów.

Tabela 4: Zestawienie wskaźników DAI dla wybranych krajów[4]

\begin{tabular}{|l|l|l|l|l|l|}
\hline Kraj & $\begin{array}{l}\text { Ro } \\
\mathbf{k}\end{array}$ & $\begin{array}{l}\text { Indeks } \\
\text { Adop- } \\
\text { cji } \\
\text { Cyfro- } \\
\text { wej }\end{array}$ & $\begin{array}{l}\text { Klaster } \\
\text { przedsiębior- } \\
\text { stwa }\end{array}$ & $\begin{array}{l}\text { Kla- } \\
\text { ster } \\
\text { Lu- } \\
\text { dzie }\end{array}$ & $\begin{array}{l}\text { Kla- } \\
\text { ster } \\
\text { Rząd }\end{array}$ \\
\hline Chiny & $\begin{array}{l}201 \\
4\end{array}$ & 0,501 & 0,471 & 0,400 & 0,632 \\
\cline { 2 - 6 } & $\begin{array}{l}201 \\
6\end{array}$ & 0,586 & 0,548 & 0,525 & 0,686 \\
\hline $\begin{array}{l}\text { Japo- } \\
\text { nia }\end{array}$ & $\begin{array}{l}201 \\
4\end{array}$ & 0,816 & 0,731 & 0,787 & 0,932 \\
\cline { 2 - 6 } & $\begin{array}{l}201 \\
6\end{array}$ & 0,835 & 0,761 & 0,835 & 0,909 \\
\hline \multirow{2}{*}{$\begin{array}{l}\text { Pol- } \\
\text { ska }\end{array}$} & $\begin{array}{l}201 \\
4\end{array}$ & 0,651 & 0,731 & 0,643 & 0,578 \\
\cline { 2 - 6 } & $\begin{array}{l}201 \\
6\end{array}$ & 0,690 & 0,756 & 0,684 & 0,631 \\
\hline
\end{tabular}

Można zauważyć, iż najwyższą wartością wskaźnika DAI w 2014 i 2016 roku wyznacza się Japonia. Oznacza to, iż spośród wymienionych krajów, poziom adopcji cyfryzacji w Japonii jest najwyższy i pozostawia daleko w tyle Chiny i Polskę. Największy wpływ na wskaźnik ma wysokość wskaźnika DAI dla rządu, podczas gdy w Polsce wskaźnik ten jest najniższy w porównaniu do pozostałych. Ta różnica może wynikać z większej centralizacji Japońskiej gospodarki względem Polskiej, jednakże tą kwestię należało by poddać dodatkowej, szczegółowej analizie, aby jednoznacznie to rozstrzygnąć. Podobna dysproporcja co w Japonii, pojawia się w Chinach, gdzie ponownie DAI rządowe jest wyraźnie wyższe od pozostałych. Podobnie, porównując subwskaźniki w Polsce i w Chinach, można zauważyć iż pomimo ogólnej przewagi Polski nad Chinami, DAI rządowy w Chinach pozostaje większy od Polskiego. Pokazuje to jak wielka jest różnica w sposobie myślenia i zarządzania gospodarką w sferze usług cyfrowych pomiędzy Polską, a Dalekim Wschodem. Nie da się również pominąć faktu, iż tak jak w porównaniu do Japonii, każdy niemal każdy subwskaźnik DAI w Polsce na przestrzeni lat jest niższy, tak w przypadku Chin sytuacja jest dokładnie odwrotna. Fakt, że dwa tak bliskie sobie kraje geograficznie jak i kulturowo posiadają tak wielką dysproporcję $\mathrm{w}$ dziedzinie cyfryzacji na niekorzyść Chin, jest zastanawiająca i z pewnością warta głębszej analizy.

Nie bez znaczenia pozostaje kwestia przyswajania cyfryzacji w przedsiębiorstwach, ponieważ pomimo różnic w pozostałych subwskaźnikach, w przypadku DAI przedsiębiorstw, wskaźnik Polski oraz Japoński jest niemal identyczny.

Ostatecznie, jeśli posługiwać się wyłącznie tym wskaźnikiem, krajem najlepiej adoptującym usługi cyfrowe w każdej płaszczyźnie (przedsiębiorstwa, obywatele, rząd) jest Japonia, a krajem wykazującym się najniższą adaptacją są Chiny.

Aby nie kierować się bezrefleksyjnie wyłącznie podanymi wartościami wskaźnika DAI, należało by przeprowadzić analizę wzbogaconą o rozpatrzenie możliwych scenariuszy dla innych komponentów wchodzących w skład wskaźnika, jako że sam Bank Światowy zaleca wprowadzenie zmian w swoim wskaźniku DAI. Z uwagi na fakt, iż dane zebrane na potrzeby poszczególnych komponentów wskaźnika nie są publicznie dostępne, nie było możliwości sprawdzenia jak zmieniłaby się wartość wskaźnika po zastąpieniu jednego, bądź kilku komponentów wchodzących w skład wskaźnika DAI innymi komponentami. Dlatego też w niniejszym opracowaniu postanowiono zamiast modyfikować opracowany już, i wciąż udoskonalany wskaźnik ekonomiczny - opracować własny, a następnie porównać wyniki.

Jak już wspomniano, niestety, nie wszystkie dane źródłowe są dostępne. W wielu przypadkach, Bank Światowy nie publikuje danych źródłowych, ani też sposobu przeliczania tych danych na potrzeby wskaźnika DAI. Tak też jest w przypadku komponentu „Strony firmowe”, czy „Zasięg 3G”. Podobnie, firmy zewnętrzne, które realizują zbieranie danych dla Banku Światowego nie zawsze są organizacjami non-profit, a zatem również nie upubliczniają tak wrażliwych danych.

\section{Własny wskaźnik cyfryzacji (DDI)}

$\mathrm{Na}$ podstawie własnej analizy oraz publicznie dostępnych danych, udało się zebrać następujące komponenty wchodzące w skład opracowywanego, autorskiego wskaźnika cyfryzacji DDI (Digital Development Index). Podzielono je na trzy grupy:

1. Płatności - wskazujące jak bardzo dany kraj wspiera płatności elektroniczne, tym samym wypierając 
płatności gotówkowe, a także w jakim stopniu wdrożone zostały rozwiązania mające na celu cyfryzację pieniądza,

2. Eksport - określa stopień cyfryzacji kraju w postaci eksportu dóbr i usług cyfrowych poza swoje granice. Przypuszczalnie, w krajach o większym stopniu cyfryzacji, poziom eksportu zaawansowanych technologii i usług z nimi związanych do innych krajów będzie wyższy,

3. Dostęp do cyfryzacji - uwzględnia rozpowszechnienie cyfryzacji i jej wpływ na życie przeciętnego obywatela, a także to, na ile prosty lub utrudniony dostęp do cyfryzacji i jej dobrodziejstw ma przeciętny człowiek żyjący w danym kraju

\subsection{Dobór wag}

Do opracowania wag dla poszczególnych elementów autorskiego wskaźnika DDI wykorzystano jedną z naukowych metod decyzyjnych i wielokryterialnego podejmowania decyzji - Multiple Criteria Desision Making (MCDM) - o nazwie AHP (Analytic Hierarchy Process), która uwzględnia przydzielanie wag poszczególnym komponentom poprzez ankietowanie ekspertów.

Zebrano opinię 10 ankietowanych osób na temat istotności stosunku poszczególnych komponentów, a także grup komponentów wchodzących w skład wskaźnika DDI. Próbką osób została grupa absolwentów studiów magisterskich o kierunku informatycznym do 28 roku życia.

Zadaniem ankietowanych było ocenić istotność stosunku pomiędzy poszczególnymi komponentami na różnych poziomach hierarchii struktury wskaźnika DDI w skali od 1 do 9.

Po zebraniu wyników i przedstawieniu ich w postaci macierzy, na skutek operacji matematycznych wyznaczane są wagi dla każdego z komponentów, a także współczynnik konsekwencji, zgodnie z procedurą stosowaną w metodologii AHP.

\subsection{Wskaźnik DDI - wyniki}

Tabele 5, 6 oraz 7 przedstawiają wyniki uzyskane dla poszczególnych klastrów autorskiego wskaźnika DDI.

Tabela 5: Klaster „Płatności” autorskiego wskaźnika

\begin{tabular}{|c|c|c|c|c|}
\hline Komponent & Kraj & Rok & Wartość & Waga \\
\hline \multirow{6}{*}{$\begin{array}{l}\text { Płatności elektro- } \\
\text { niczne wykorzysty- } \\
\text { wane do dokonywa- } \\
\text { nia płatności }\end{array}$} & \multirow[t]{2}{*}{ Polska } & 2014 & 0,343 & \multirow[t]{6}{*}{0,397} \\
\hline & & 2016 & - & \\
\hline & \multirow[t]{2}{*}{ Japonia } & 2014 & 1 & \\
\hline & & 2016 & - & \\
\hline & \multirow[t]{2}{*}{ Chiny } & 2014 & 0 & \\
\hline & & 2016 & - & \\
\hline \multirow{6}{*}{$\begin{array}{l}\text { Telefony komórko- } \\
\text { we wykorzystywane } \\
\text { do płacenia rachun- } \\
\text { ków }\end{array}$} & \multirow[t]{2}{*}{ Polska } & 2014 & 1 & \multirow[t]{6}{*}{0,237} \\
\hline & & 2016 & - & \\
\hline & \multirow[t]{2}{*}{ Japonia } & 2014 & 0 & \\
\hline & & 2016 & - & \\
\hline & \multirow[t]{2}{*}{ Chiny } & 2014 & 0,579 & \\
\hline & & 2016 & - & \\
\hline Liczba bankomatów & Polska & 2014 & 0,119 & 0,157 \\
\hline
\end{tabular}

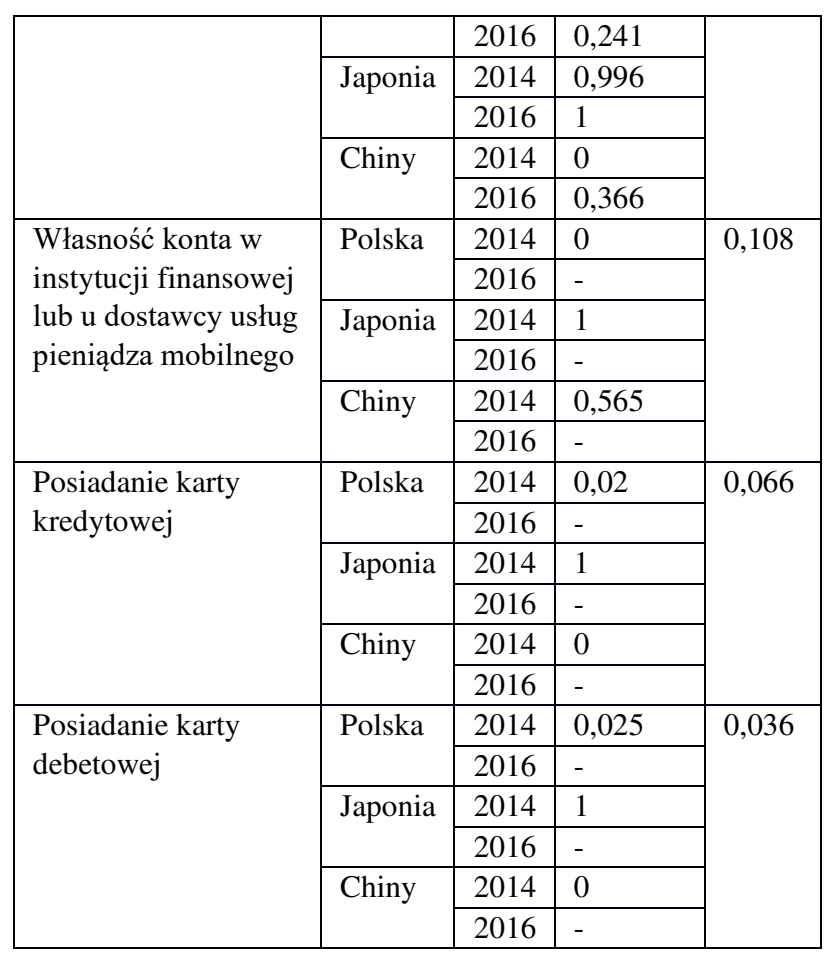

Tabela 6: Klaster „Eksport” autorskiego wskaźnika

\begin{tabular}{|c|c|c|c|c|}
\hline Komponent & Kraj & Rok & Wartość & Waga \\
\hline \multirow{6}{*}{$\begin{array}{l}\text { Eksport towarów } \\
\text { ICT }\end{array}$} & \multirow[t]{2}{*}{ Polska } & 2014 & 0,031 & \multirow[t]{6}{*}{0,648} \\
\hline & & 2016 & 0 & \\
\hline & \multirow[t]{2}{*}{ Japonia } & 2014 & 0,670 & \\
\hline & & 2016 & 0,619 & \\
\hline & \multirow[t]{2}{*}{ Chiny } & 2014 & 0,969 & \\
\hline & & 2016 & 1 & \\
\hline \multirow[t]{6}{*}{ Eksport usług ICT } & \multirow[t]{2}{*}{ Polska } & 2014 & 0,657 & \multirow[t]{6}{*}{0,253} \\
\hline & & 2016 & 0,853 & \\
\hline & \multirow[t]{2}{*}{ Japonia } & 2014 & 0 & \\
\hline & & 2016 & 0,020 & \\
\hline & \multirow[t]{2}{*}{ Chiny } & 2014 & 0,706 & \\
\hline & & 2016 & 1 & \\
\hline \multirow{6}{*}{$\begin{array}{l}\text { Stosunek eksportu } \\
\text { zaawansowanych } \\
\text { technologii do } \\
\text { produkowanego } \\
\text { eksportu }\end{array}$} & \multirow[t]{2}{*}{ Polska } & 2014 & 0,012 & \multirow[t]{6}{*}{0,451} \\
\hline & & 2016 & 0 & \\
\hline & \multirow[t]{2}{*}{ Japonia } & 2014 & 0,485 & \\
\hline & & 2016 & 0,456 & \\
\hline & \multirow[t]{2}{*}{ Chiny } & 2014 & 1 & \\
\hline & & 2016 & 0,988 & \\
\hline
\end{tabular}

Tabela 7: Klaster „Dostęp do cyfryzacji” autorskiego wskaźnika

\begin{tabular}{|c|c|c|c|c|}
\hline Komponent & Kraj & Rok & Wartość & Waga \\
\hline \multirow{6}{*}{$\begin{array}{l}\text { Gospodarstwa do- } \\
\text { mowe } z \text { dostępem do } \\
\text { internetu }\end{array}$} & \multirow[t]{2}{*}{ Polska } & 2014 & 0,543 & \multirow[t]{6}{*}{0,411} \\
\hline & & 2016 & 0,622 & \\
\hline & \multirow[t]{2}{*}{ Japonia } & 2014 & 0,809 & \\
\hline & & 2016 & 1 & \\
\hline & \multirow[t]{2}{*}{ Chiny } & 2014 & 0 & \\
\hline & & 2016 & 0,168 & \\
\hline \multirow{6}{*}{$\begin{array}{l}\text { Osoby korzystające } \mathrm{z} \\
\text { internetu }\end{array}$} & \multirow[t]{2}{*}{ Polska } & 2014 & 0 & \multirow[t]{6}{*}{0,234} \\
\hline & & 2016 & 0,252 & \\
\hline & \multirow[t]{2}{*}{ Japonia } & 2014 & 0,846 & \\
\hline & & 2016 & 1 & \\
\hline & \multirow[t]{2}{*}{ Chiny } & 2014 & 0,846 & \\
\hline & & 2016 & 1 & \\
\hline Stałe subskrypcje & Polska & 2014 & 0,268 & 0,147 \\
\hline
\end{tabular}




\begin{tabular}{|c|c|c|c|c|}
\hline \multirow[t]{5}{*}{ szerokopasmowe } & & 2016 & 0,286 & \\
\hline & \multirow[t]{2}{*}{ Japonia } & 2014 & 0,899 & \\
\hline & & 2016 & 1 & \\
\hline & \multirow[t]{2}{*}{ Chiny } & 2014 & 0 & \\
\hline & & 2016 & 0,512 & \\
\hline \multirow{6}{*}{$\begin{array}{l}\text { Liczba bezpiecznych } \\
\text { serwerów }\end{array}$} & \multirow[t]{2}{*}{ Polska } & 2014 & 0,270 & \multirow[t]{6}{*}{0,115} \\
\hline & & 2016 & 1 & \\
\hline & \multirow[t]{2}{*}{ Japonia } & 2014 & 0,551 & \\
\hline & & 2016 & 0,846 & \\
\hline & \multirow[t]{2}{*}{ Chiny } & 2014 & 0 & \\
\hline & & 2016 & 0,153 & \\
\hline \multirow{6}{*}{$\begin{array}{l}\text { Subskrypcje telefo- } \\
\text { nów komórkowych }\end{array}$} & \multirow[t]{2}{*}{ Polska } & 2014 & 1 & \multirow[t]{6}{*}{0,06} \\
\hline & & 2016 & 0,828 & \\
\hline & \multirow[t]{2}{*}{ Japonia } & 2014 & 0,544 & \\
\hline & & 2016 & 0,673 & \\
\hline & \multirow[t]{2}{*}{ Chiny } & 2014 & 0 & \\
\hline & & 2016 & 0,08 & \\
\hline \multirow{6}{*}{$\begin{array}{l}\text { Stałe abonamenty } \\
\text { telefoniczne }\end{array}$} & \multirow[t]{2}{*}{ Polska } & 2014 & 0,041 & \multirow[t]{6}{*}{0,032} \\
\hline & & 2016 & 0 & \\
\hline & \multirow[t]{2}{*}{ Japonia } & 2014 & 0,984 & \\
\hline & & 2016 & 1 & \\
\hline & \multirow[t]{2}{*}{ Chiny } & 2014 & 0,117 & \\
\hline & & 2016 & 0,029 & \\
\hline
\end{tabular}

\section{Wnioski}

Opierając się na wskaźniku DAI jako wzorcu do porównań, a także po obliczeniu wartości autorskiego wskaźnika DDI dla każdego z trzech wymienionych krajów za lata 2014-2016 otrzymano zestawienie przedstawione w tabelach 8 i 9.

Tabela 8: Zestawienie wskaźników DAI dla wybranych krajów [4]

\begin{tabular}{|c|c|c|c|c|c|}
\hline Kraj & Rok & $\begin{array}{l}\text { In- } \\
\text { deks } \\
\text { Ad- } \\
\text { opcji } \\
\text { Cy- } \\
\text { fro- } \\
\text { wej }\end{array}$ & $\begin{array}{l}\text { Klaster } \\
\text { przedsiębior- } \\
\text { stwa }\end{array}$ & $\begin{array}{l}\text { Kla- } \\
\text { ster } \\
\text { Lu- } \\
\text { dzie }\end{array}$ & $\begin{array}{l}\text { Klaster } \\
\text { Rząd }\end{array}$ \\
\hline \multirow{2}{*}{$\begin{array}{l}\text { Pol- } \\
\text { ska }\end{array}$} & 2014 & 0,651 & 0,731 & 0,643 & 0,578 \\
\hline & 2016 & 0,690 & 0,756 & 0,684 & 0,631 \\
\hline \multirow{2}{*}{$\begin{array}{l}\text { Japo- } \\
\text { nia }\end{array}$} & 2014 & 0,816 & 0,731 & 0,787 & 0,932 \\
\hline & 2016 & 0,835 & 0,761 & 0,835 & 0,909 \\
\hline \multirow{2}{*}{$\begin{array}{l}\text { Chi- } \\
\text { ny }\end{array}$} & 2014 & 0,501 & 0,471 & 0,400 & 0,632 \\
\hline & 2016 & 0,586 & 0,548 & 0,525 & 0,686 \\
\hline
\end{tabular}

Tabela 9: Wyniki autorskiego wskaźnika DDI

\begin{tabular}{|l|l|l|l|l|l|}
\hline Kraj & Rok & $\begin{array}{l}\text { Wyniki } \\
\text { calkowite }\end{array}$ & $\begin{array}{l}\text { Platno- } \\
\text { ści }\end{array}$ & Eksport & $\begin{array}{l}\text { Dostęp } \\
\text { do } \\
\text { cyfry- } \\
\text { zacji }\end{array}$ \\
\hline Polska & 2014 & 0,224 & 0,394 & 0,142 & 0,355 \\
\cline { 2 - 6 } & 2016 & 0,248 & - & 0,160 & 0,552 \\
\hline \multirow{2}{*}{ Japonia } & 2014 & 0,703 & 0,763 & 0,483 & 0,815 \\
\cline { 2 - 6 } & 2016 & 0,567 & - & 0,453 & 0,963 \\
\hline Chiny & 2014 & 0,368 & 0,198 & 0,930 & 0,202 \\
\cline { 2 - 6 } & 2016 & 0,863 & - & 0,996 & 0,402 \\
\hline
\end{tabular}

\subsection{Analiza wyników}

Porównując wyniki obu wskaźników, najbardziej rzuca się w oczy fakt, iż we wskaźniku DDI Polska wypada znacznie gorzej. Wynika to $\mathrm{w}$ największej mierze z najniższego poziomu eksportu zaawansowanych technologii, w których prym wiodą Chiny, zostawiając tak Polskę jak i Japonię daleko w tyle. Jednak wskaźnik eksportu nie jest jedynym niekorzystnym wskaźnikiem dla Polski, ponieważ pozostałe również nie znajdują się na wysokim poziomie. Nawet jeśli Polska przewyższa Chiny pod względem cyfryzacji w sferze płatności oraz dostępu do cyfryzacji dla obywateli swojego kraju, to z uwagi na tę niekorzystną dla Polski różnicę w eksporcie zaawansowanych technologii, wynik całkowity dla Polski jest blisko o połowę niższy.

Z kolei Japonia zdecydowanie zdominowała sferę płatności, jak i dostępu do cyfryzacji. Wynik końcowy Japonii jest zdecydowanie najlepszy spośród wszystkich krajów w rozpatrywanym autorskim wskaźniku DDI, co świadczy o wysokim poziomie cyfryzacji.

Warto również poruszyć kwestię różnicy wartości wskaźnika dla Japonii oraz Chin w roku 2016 względem roku 2014. Wynika to $\mathrm{z}$ faktu, iż nie opublikowano wyników dla komponentów znajdujących się w klastrze „płatności” za rok 2016. W związku z tym, iż dane te nie zostały uwzględnione, wyniki za 2016 rok nie uwzględniają wpływu tego klastra na ostateczny wynik. W przypadku Japonii, która w sferze płatności odnotowuje najwyższy poziom cyfryzacji, wiąże się to ze spadkiem o niemal 0,15. Ponadto, w roku 2016 Japonia odnotowuje niższy poziom eksportu. Różnica ta wynika prawdopodobnie $\mathrm{z}$ dominującej pozycji Chin, które wraz z upływem czasu coraz bardziej rozwijają swój eksport, przez co ucierpiał wynik dla Japonii. W przypadku Chin z kolei, z uwagi na to, iż w 2014 roku poziom cyfryzacji w sferze płatności był najniższy $z$ pośród wszystkich rozpatrywanych krajów, z powodu jego utraty pozostałe dwa wskaźniki (w tym przede wszystkim eksport) uzyskały większy wpływ na ostateczny wynik - stąd tak ogromna różnica. Ponadto, warto zwrócić uwagę na fakt, iż Chiny odnotowują niemal dwa razy wyższą wartość wskaźnika „dostęp do cyfryzacji”, co również miało duży wpływ na ostateczny wynik za rok 2016.

\subsection{Wnioski końcowe}

Przedsięwzięcie zmierzenia poziomu cyfryzacji w różnych krajach na świecie o różnych gospodarkach, kulturach i sytuacjach geopolitycznych $\mathrm{z}$ pewnością jest zadaniem trudnym. Nie istnieje jeden poprawny sposób, w jaki można by dokonać pomiarów cyfryzacji, a każdy wskaźnik opracowany przez różne podmioty i składających się z innych komponentów, nie jest wolny od wad i możliwości do ulepszeń. Podobnie wskaźnik DDI, który z pewnością nie jest idealny i posiada wiele wad. $\mathrm{Z}$ pewnością jednak, badania w zakresie pomiarów poziomu cyfryzacji na świecie, a także nowe sposoby jego wyznaczania sa potrzebne i powinny być kontynuowane, jako że istnieje zapotrzebowanie na tego rodzaju informacje, jak i z uwagi na to, że zagadnienie to 
jest zbyt złożone aby jedna instytucja była w stanie objąć wszelkie dostępne zmienne mogące mieć wpływ na poziom cyfryzacji. W procesie opracowywania wskaźnika cyfryzacji ważne jest przede wszystkim uwzględnienie jak największej liczby zmiennych, przemyślana struktura wskaźnika, jak i nieskrępowany dostęp do danych. W sytuacji gdy duże koncerny i korporacje są $\mathrm{w}$ stanie wydać mnóstwo pieniędzy na pozyskanie danych poprzez przeprowadzenie ankiet bądź dane zebrane $\mathrm{z}$ innych podmiotów gospodarczych lub państwowych, przeciętny absolwent uczelni nie jest w stanie pozyskać dostępu do tak kluczowych na potrzeby analizy danych. Z pomocą przychodzi instytucja Banku Światowego, która udostępnia niektóre zebrane dane na temat cyfryzacji. Jednak zagłębiając się w temat analizy wskaźników cyfryzacji, po pewnym czasie można zauważyć, iż liczba tych danych, ich aktualność, a także zakres tematyki, jest wciąż niesatysfakcjonująca, jako że bardzo trudno jest opracować wskaźnik cyfryzacji, który byłby rzetelny i trafny co do faktycznej sytuacji w danych miejscach na świecie na podstawie tych dostępnych publicznie danych. $\mathrm{Z}$ pewnością $\mathrm{w}$ tej sytuacji pomogło by uchylenie rąbka tajemnicy odnośnie szczegółów konstrukcji wskaźnika cyfryzacji, a także danych jakie udało się zebrać dla poszczególnych elementów wchodzacych w ich skład. Tym niemniej, warto pamiętać o tym, iż tematyka cyfryzacji, jej pomiarów oraz sposobów wyznaczania wciąż się rozwija - podobnie jak dostęp do informacji, który z roku na rok staje się coraz bardziej powszechny.

\section{Literatura}

[1] Słownik języka polskiego (sjp) - „Dygitalizacja”: https://sip.pwn.pl/sjp/dygitalizacja;2555621.html [23.10.2019]

[2] Wikipedia: https://pl.wikipedia.org/wiki [23.10.2019]

[3] Transformacja zmiennych diagnostycznych: http://webcache.googleusercontent.com/search?q=cache: dGhpC70RX9gJ:kolegia.sgh.waw.pl/pl/KAE/struktura/IS iD/struktura/ZSS/zaklad/sklad/Strony/oferta dydaktyczn a $\_$panek.aspx $+\& \mathrm{~cd}=1 \& \mathrm{hl}=\mathrm{pl} \& \mathrm{ct}=\mathrm{clnk} \& \mathrm{gl}=\mathrm{pl}$ [23.10.2019]

[4] World Development Report 2016: Digital Dividends: http://www.worldbank.org/en/publication/wdr2016 [23.10.2019]

[5] Gallup Poll: https://www.gallup.com/analytics/ 232838/world-poll.aspx [23.10.2019]

[6] Bank Światowy: Indeks Adopcji Cyfrowej metodologia (2016): http://pubdocs.Worldbank.org/en/58722147 5074960682/WDR16-BP-DAI- methodology.pdf [3.10.2019] 